\title{
Real-Time PCR Quantification of Peronospora arborescens, the Opium Poppy Downy Mildew Pathogen, in Seed Stocks and Symptomless Infected Plants
}

\author{
Miguel Montes-Borrego, Department of Crop Protection, Institute of Sustainable Agriculture (IAS), Spanish National Research Coun- \\ cil (CSIC), P.O. Box 4084, 14080 Córdoba, Spain, and College of Agriculture and Forestry (ETSIAM), University of Córdoba (UCO), \\ Campus de Rabanales, Ctra. Madrid-Cádiz, km 396, 14071 Córdoba, Spain; Francisco J. Muñoz-Ledesma, ALCALIBER I+D+i, S.L., \\ Ctra. Carmona-El Viso del Alcor, km 1.8, Carmona (Sevilla), Spain; Rafael M. Jiménez-Díaz, Department of Crop Protection, IAS- \\ CSIC and ETSIAM-UCO, Córdoba, Spain; and Blanca B. Landa, Department of Crop Protection, IAS-CSIC
}

\begin{abstract}
Montes-Borrego, M., Muñoz-Ledesma, F. J., Jiménez-Díaz, R. M., and Landa, B. B. 2011. Real-time PCR quantification of Peronospora arborescens, the opium poppy downy mildew pathogen, in seed stocks and symptomless infected plants. Plant Dis. 95:143-152.

In this study, we developed a reliable, quick, and accurate quantitative polymerase chain reaction (qPCR) assay based on the MIQE (Minimum Information for publication of Quantitative Real-Time PCR Experiments) guidelines for the quantification of Peronospora arborescens in infected downy mildew-symptomless opium poppy (Papaver somniferum) tissues and commercial seed stocks. The protocol was highly reproducible and allowed accurate quantification of pathogen DNA up to $10 \mathrm{fg}$ in different plant DNA backgrounds without losing specificity and efficiency. Moreover, to further overcome difficulties conferred by the strict biotrophy of this pathogen, we developed dilution series of DNA extracted from a plasmid with the target pathogen

DNA as a cloned insert. This facilitated the demonstration of the robustness of the protocol in different laboratories with different qPCR equipment and reagents, which may help in its use on a broad scale. Finally, we validated the usefulness of the qPCR protocol for quarantine purposes and downy mildew resistance screening by quantifying $P$. arborescens in complex, naturally infested opium poppy samples. Thus, a pathogen biomass of 0.0003 to $0.007 \%$ or of 0.110 to 5,557 ppm was quantified in symptomless capsules in commercial seed stocks, or in stem samples from symptomless opium poppy plants systemically infected by the pathogen, respectively.
\end{abstract}

Opium poppy (Papaver somniferum) is the only source of pharmaceutical codeine, morphine, and thebaine, key drugs for alleviation of chronic pain. In Spain, opium poppy is grown annually on approximately 9,500 ha, primarily in the southern (Andalucía) and central (Castilla-La Mancha and Castilla-León) regions of the country $(27,33,34)$. This acreage accounts for at least $5 \%$ of the legally cultivated opium poppy worldwide, making Spain the third largest European and fourth largest world producer of poppy straw rich in morphine (23). In Spain, ALCALIBER S.A. (Carmona, Sevilla, Spain) is the only enterprise officially authorized for opium poppy cultivation and alkaloids extraction for pharmaceutical use.

Opium poppy crops in Spain can be affected by several diseases of diverse etiology $(2,26,27)$. However, during the last 5 years, downy mildew has become the main yield-limiting factor for this crop in Spain $(33,34)$. Downy mildew epidemics occur throughout all opium poppy-growing areas in Spain, and their incidence and severity have increased steadily since the disease was first recorded (26). In Spain and France, downy mildew in opium poppy commercial fields is caused by the obligate biotrophic oomycete Peronospora arborescens $(26,32)$, whereas in Australia the disease is caused by $P$. cristata (41).

The exact detection and proper identification of the causal agent are essential for the effective control of a plant disease, and hence of opium poppy downy mildew. During the last 15 years, molecular techniques based mainly on conventional polymerase chain reaction (PCR) assays have emerged as a major tool for diagnosing and identifying phytopathogenic fungi. These techniques have alleviated some of the problems associated with the detection,

Corresponding author: B. B. Landa, E-mail: blanca.landa@ias.csic.es

Accepted for publication 30 September 2010.

doi:10.1094/PDIS-07-10-0499

(C) 2011 The American Phytopathological Society control, and containment of plant pathogens $(17,30)$. The technology has also been used in the development of molecular protocols for detection of $P$. arborescens in different plant tissues $(27,33)$. In recent work $(27,33), P$. arborescens-specific simple- and nestedPCR protocols using two sets of primer pairs (OMPac1fw/OMPac1rv or OMPac7fw/OMPac7rv; Spanish patent applications P200803261 and P200803262) were developed that: (i) can be used for $P$. arborescens detection in capsules, leaves, roots, seeds, and stems of opium poppy plants; (ii) are sensitive enough to detect from 0.1 to $10 \mathrm{pg}$ (simple-PCR) or from 5 to $0.5 \mathrm{fg}$ (nested-PCR) of $P$. arborescens DNA against a background of 25 to $50 \mathrm{ng}$ of opium poppy DNA; and (iii) are highly specific with no cross-amplification with other closely related pathogens in infected opium poppy tissues, especially $P$. cristata.

Since $P$. arborescens is a nonculturable, strictly biotrophic plant pathogen, availability of $P$. arborescens-specific PCR protocols has enabled significant progress in our understanding of the biology of this pathosystem. The use of these protocols allowed us to demonstrate important aspects in the cycle of pathogenesis of this downy mildew disease, including: (i) the main role of oospores as primary inoculum, and (ii) the occurrence of asymptomatic, systemic infections that can give rise to seed infection and pathogen transmission $(27,33,34)$. However, one of the limitations of the developed PCR protocols is that they do not allow quantifying the amount of pathogen infection in the plant. Overcoming that limitation by means of a quantitative and sensitive PCR method would be particularly useful for epidemiological studies, quarantine, and disease control schemes. In particular, such a method would be useful to: (i) discriminate between resistant and tolerant opium poppy germplasm in breeding for resistance to the pathogen by quantifying the pathogen in symptomatic and asymptomatic infections, and (ii) correlate the amount of pathogen in infected plant tissues with the subsequent level of disease development in resistant/tolerant germplasm and/or after use of other disease control measures.

Quantitative real-time PCR (qPCR) was introduced for the monitoring of plant pathogens directly from plant tissues at the end of the 
1990s, and since then it has been adapted for use in many plant pathosystems (reviewed by 36,37,39). In the case of oomycetes, most of the developed qPCR assays target different species of $P y$ thium $(4,40)$ and Phytophthora $(4,6,7,24,38,42,47,48)$. Also, qPCR assays have been developed for the strictly biotrophic oomycetes Plasmopara viticola (46) and some Peronospora spp., including $P$. sparsa (21), P. parasitica (9), and unidentified Peronospora spp. (5).

In the present study, we report the development of a reliable, quick, and economical real-time qPCR assay following the MIQE (Minimum Information for publication of Quantitative Real-Time PCR Experiments) guidelines (10) for the identification and quantification of $P$. arborescens DNA in different opium poppy tissues (Patent application no. P200901627; PCT/ES2010/070506). By following the MIQE guidelines, we provide the minimum information required for a $\mathrm{qPCR}$ experiment to quantify $P$. arborescens DNA that ensures its relevance, accuracy, correct diagnosis, and repeatability (10).

\section{Materials and Methods}

Plant and pathogen material. Seeds of commercial opium poppy cv. Nigrum provided by ALCALIBER S.A. (own seed stocks) were used throughout the study. Seeds were demonstrated free from infection by negative amplification of $P$. arborescens in nested, species-specific PCR assays (33). Seeds were surfacedisinfested in $1 \% \mathrm{NaOCl}$ for $5 \mathrm{~min}$, rinsed twice with sterile ultrapure water (SUW), dried in a flow hood, and stored in sterile conditions until used for experiments. To obtain mature leaf tissues, seeds were germinated for 1 week on sterile layers of filter paper moistened with $2 \mathrm{ml}$ of sterile $50 \%$ Hoagland solution (20) in 9-cm-diameter petri dishes at $20^{\circ} \mathrm{C}$. Then, seedlings were transplanted into a pasteurized $\left(70^{\circ} \mathrm{C}, 60 \mathrm{~min}\right)$ soil mixture (clay loam/peat, 2:1, vol/vol) in pots and incubated in a growth chamber (Sanyo MLR-350 H, Sanyo Electric Co., Ltd., Japan) at $20^{\circ} \mathrm{C}$, $70 / 90 \%$ relative humidity (RH), and a 12-h photoperiod of fluorescent light at $360 \mu \mathrm{E} \cdot \mathrm{m}^{-2} \cdot \mathrm{s}^{-1}$ for 40 days.

Samples of $P$. arborescens were obtained from opium poppy plant leaves with fresh pathogen sporulation from artificially inoculated plants incubated in a growth chamber (34). For DNA extraction, a sporangium suspension without host tissue was obtained as previously described (27). Samples for construction of plasmids were obtained from sporulated leaves of naturally infected opium poppy plants in commercial crops at "Casilla San José" farms, Écija, Sevilla province, Spain.

Construction of control plasmids. The internal transcribed spacers ITS1 and ITS2 and 5.8S region of rDNA from a specimen of $P$. arborescens (EC3_P38ESJ, 27) in our culture collection was amplified using primer pair DC6 (8)/ITS4 and ligated into pGEMT Easy Vector System I (Promega, Madison, WI) using Escherichia coli strain JM109 for transformation as described earlier (27). The correct cloning was confirmed by sequencing the cloned insert in both directions using universal primers (27) on a DNA multicapillary sequencer (ABI Prism 3100 genetic analyzer, Applied Biosystems, Foster City, CA) at the University of Córdoba sequencing facilities. The selected transformed clone was stored in glycerol $(20 \%)$ at $-80^{\circ} \mathrm{C}$ and cultured when needed.

DNA extraction and quantification. Genomic DNA of $P$. arborescens (sporangia suspension) and opium poppy seeds and leaves were extracted using the G-SpinTM II Plant Genomic DNA extraction kit (Intron Biotechnology, Suwon, Korea) and the Fast Prep System Bio 101 (Qbiogene, Madrid, Spain) according to Landa et al. (27).

Plasmid DNA was extracted from cultures of E. coli strain JM109 grown overnight at $37^{\circ} \mathrm{C}$ in Luria-Bertani (LB) broth (10 g of tryptone, $5 \mathrm{~g}$ of yeast extract, $5 \mathrm{~g}$ of $\mathrm{NaCl}, 1$ liter of $\mathrm{H}_{2} \mathrm{O}$ [pH 7.2]) supplemented with ampicillin $(100 \mu \mathrm{g} / \mathrm{ml})$ using the QuickGene Plasmid Kit (Fujifilm Corporation, Tokyo, Japan) and QuickGene-Mini80 device (Fujifilm) according to the manufacturer's instructions.

DNA quality was assessed by gel electrophoresis and ethidium bromide staining. All DNA samples were accurately quantified using the Quant-iT DNA Assay Kit Broad Range fluorometric assay (Molecular Probes Inc., Leiden, The Netherlands) and a
Tecan Safire fluorospectrometer (Tecan Spain, Barcelona, Spain) (27). For plasmid, pathogen, and host DNA, each sample was run in triplicate, in two independent microplates and days. Samples of opium poppy and $P$. arborescens DNA of known concentration were included in each quantification plate as an internal control of DNA quantification. Genomic and plasmid DNA were diluted with SUW as appropriate.

DNA dilution series. DNA dilution series were obtained from 10-fold dilutions of pure $P$. arborescens genomic DNA obtained from sporangia suspensions (G-series) or of linearized plasmid DNA (P-series). For this purpose, $P$. arborescens genomic DNA (1 $\mathrm{ng} / \mu \mathrm{l})$ or plasmid DNA ( $1 \mathrm{ng} / \mu \mathrm{l}$; equivalent to $2.165 \times 10^{8}$ copies/ $\mu \mathrm{l})$ were serially diluted $\left(1: 1\right.$ to $1: 10^{5}$ [G-series] or $1: 1$ to $1: 10^{6}$ [P-series]) in SUW ( $\mathrm{G}_{\mathrm{W}}$ and $\mathrm{P}_{\mathrm{W}}$ dilution series) as well as in a fixed background of Papaver somniferum DNA (40 ng/ $\mu \mathrm{l}$ ) extracted from healthy opium poppy leaves $\left(\mathrm{G}_{\mathrm{L}}\right.$ and $\mathrm{P}_{\mathrm{L}}$ dilution series) and seeds $\left(G_{S}\right.$ and $P_{S}$ dilution series). Each dilution series always included Papaver somniferum DNA and no-DNA negative controls. In the initial steps of assay optimization, DNA of $P$. cristata was included to confirm that no cross-amplification occurs in the qPCR assay as it was shown previously (27).

Ten different DNA dilution series (five for G-series, designated G1 to 5, and five for P-series, designated P1 to 5) were obtained using different plant and pathogen combinations of DNA sources (i.e., opium poppy leaves of different age [mature leaves and cotyledons], leaves and seeds from different origin, $P$. arborescens sporangia from sporulating leaves in the field or growth chamber, different plasmid cultures, freeze/defrost cycles, etc.) to test for the effect of those factors in the efficiency of amplification (Table 1). Following the development of the $\mathrm{G} 1_{\mathrm{W}}-5_{\mathrm{W}}$ and $\mathrm{P} 1_{\mathrm{W}}-5_{\mathrm{W}}$ DNA dilution series, each dilution point was quantified in triplicate by using the fluorometric Quant-iT High Sensitivity DNA assay kit (Molecular Probes Inc.) assuming same pathogen DNA in the $\mathrm{G} 1_{\mathrm{L}}-5_{\mathrm{L}}$, $\mathrm{G} 1_{\mathrm{S}}-5_{\mathrm{S}}$, and $\mathrm{P} 1_{\mathrm{L}}-5_{\mathrm{L}}$, and $\mathrm{P} 1_{\mathrm{S}}-5_{\mathrm{S}}$ DNA dilution series.

Optimization, reproducibility, and sensitivity of the real-time qPCR protocol. All real-time PCR amplifications were performed using the iQ SYBR Green Supermix (BioRad, Madrid, Spain) and the iCycler IQ apparatus (BioRad). In the initial stages of optimization of the real-time PCR assay, we evaluated the cycling conditions and primer pairs P3Pa2fw/P3Pa12rv (set P2), OMPac1fw/OMPac1rv (set P3), and OMPac7fw/OMPac7rv (set P6) using DNA dilution series $\mathrm{G} 1_{\mathrm{W}}$ and $\mathrm{G} 1_{\mathrm{S}}$. These primer pairs were previously designed by Landa et al. (27) to specifically amplify a fragment of the $P$. arborescens ITS region. For this experiment, an initial concentration of $10 \mathrm{ng}$, but not the lowest pathogen concentration of $100 \mathrm{fg}$, were included. Reaction conditions to measure the fluorescence signal of the amplicon (i.e., volume of reaction, annealing temperature, and primer concentration) were adjusted experimentally to optimize the real-time qPCR protocol. Fluorescence of the target amplicon (melting temperature $[\mathrm{Tm}]=$ $86.5^{\circ} \mathrm{C}$ ) was detected at $83^{\circ} \mathrm{C}$. After the final amplification cycle, a melting curve profile was obtained by heating to $95^{\circ} \mathrm{C}$, cooling to $72^{\circ} \mathrm{C}$, and slowly heating to $95^{\circ} \mathrm{C}$ at $0.5^{\circ} \mathrm{C}$ every $10 \mathrm{~s}$, with continuous measurement of fluorescence at $520 \mathrm{~nm}$ to detect if unspecific products or primer dimers occurred. All reactions were analyzed by gel electrophoresis to confirm that only one PCR product was amplified from the samples with genomic DNA of $P$. arborescens and no amplification product was obtained from the negative controls.

To investigate any possible influence of host DNA on the accuracy of amplification and quantification of target DNA (genomic or plasmid), two DNA dilution series $\left(\mathrm{G} 1_{\mathrm{W}, \mathrm{L}, \mathrm{S}^{-}} \mathrm{G} 2_{\mathrm{W}, \mathrm{L}, \mathrm{S}}\right.$ and $\mathrm{P} 1_{\mathrm{W}, \mathrm{L}, \mathrm{S}^{-}}$ $\mathrm{P} 2_{\mathrm{W}, \mathrm{L}, \mathrm{S}}$ ) and primer pair OMPac7fw/OMPac7rv (set P6) were used. Real-time reactions for each DNA dilution series were performed independently. All DNA backgrounds were assayed in the same 96well PCR plate, with each experimental combination being replicated twice and in two independent experiments (different PCR plates and operators).

To further evaluate robustness and efficiency of the real-time qPCR protocol, the five DNA dilution series obtained with differ- 
ent sources of genomic $P$. arborescens DNA $\left(\mathrm{G} 1-5_{\mathrm{L}}\right.$ and $\left.\mathrm{G} 1-5_{\mathrm{S}}\right)$ and of plasmid EC3_P38ESJ DNA (P1-5 and P1-5 $)$ (Table 1) were assessed in two-by-two series $\left(\mathrm{G} 1_{\mathrm{L}, \mathrm{S}} \mathrm{P} 1_{\mathrm{L}, \mathrm{S}}, \mathrm{G} 2_{\mathrm{L}, \mathrm{S}} \mathrm{P} 2_{\mathrm{L}, \mathrm{S}}\right.$, $\mathrm{G} 3_{\mathrm{L}, \mathrm{S}}-\mathrm{P} 3_{\mathrm{L}, \mathrm{S}}, \mathrm{G} 4_{\mathrm{L}, \mathrm{S}}-\mathrm{P} 4_{\mathrm{L}, \mathrm{S}}$, and $\left.\mathrm{G} 5_{\mathrm{L}, \mathrm{S}}-\mathrm{P} 5_{\mathrm{L}, \mathrm{S}}\right)$ in the same PCR plate. Quantitative PCR amplifications of each DNA dilution series included two replications per plate and were repeated twice in independent experiments (PCR plates and operators).

The robustness and reproducibility of the real-time qPCR protocol and the plasmid DNA dilution series was tested in different laboratories (Crop Health Research Group Laboratory at the Institute of Sustainable Agriculture [IAS], Spanish National Research Council [CSIC], Córdoba, Spain and Unidad de Genómica at the Servicio Central de Apoyo a la Investigación [SCAI], University of Córdoba) using different reagents with the P4- $5_{\mathrm{L}}$-DNA dilution series and the qPCR commercial kits sensiMixPlus SYBR kit (Quantace, London, UK), iTaq SYBR Green Supermix (Bio-Rad), and FastStart Universal SYBR Green Master (Rox) (Roche Diagnostics Corp., Indianapolis, IN). Also, two different sets of equipment were used: Real Time PCR 7500 Fast (Applied Biosystems) at the SCAI-University of Cordoba laboratory, Córdoba, Spain and the iCycler IQ apparatus (BioRad) at the IAS-CSIC laboratory using the appropriate brand reagents for each equipment but identical amplification conditions.

Finally, we assessed the sensitivity of the real-time qPCR protocol using primer set P6. To this aim, two DNA dilution series (G1-2 $2_{\mathrm{W}, \mathrm{S}, \mathrm{L}}$ and $\left.\mathrm{P} 1-2_{\mathrm{W}, \mathrm{S}, \mathrm{L}}\right)$ were used for comparing the new species-specific real-time qPCR protocol with the simple- and nested-PCR protocols previously developed for in planta $P$. arborescens detection $(27,33)$. Also, to test for the presence of false negatives, we spiked $0.1 \mathrm{ng}$ of pathogen DNA in each sample that failed to amplify using the qPCR assay to ensure the lack of PCR inhibition.
Analysis of $P$. arborescens-infected opium poppy plants and seeds by real-time qPCR. The developed real-time qPCR protocol was validated for assessing resistance or tolerance of opium poppy germplasm to $P$. arborescens. For that, 50 asymptomatic but systemically infected opium poppy plants (as determined by the nested-PCR detection assay) from artificial inoculation experiments in a previous study (34) were used. Those plants grew asymptomatically under controlled conditions in a soil naturally infested with $P$. arborescens oospores and were sampled when capsule formation occurred in the main stem. Total DNA was extracted from a 4- to 5$\mathrm{cm}$-long piece of the basal stem of each plant, as previously described (34), and used for detection and quantification of $P$. arborescens infection. DNA dilution series $\mathrm{G} 4_{\mathrm{L}}$ and $\mathrm{P} 4_{\mathrm{L}}$ in each of three independent plates were used for these real-time qPCR assays, with two replications per each DNA sample.

Use of the real-time qPCR protocol for quantifying $P$. arborescens inoculum in seeds was validated using DNA samples extracted from 11 commercial seed stocks (three replications/seed stock) obtained for a previous study (34). Those seed stocks had been selected by ALCALIBER S.A. from previous-year commercial fields with no apparent or nil (0 to 1 affected plant per $\left.\mathrm{m}^{2} ; 34\right)$ downy mildew incidence and were intended for use for commercial sowings. Also, DNA was extracted from seeds harvested from capsules of 30 arbitrarily chosen opium poppy plants grown in a field with a disease incidence of $\sim 5 \%$, as described by Landa et al. (27). Of those 30 capsules, 19 showed downy mildew symptoms of variable severity and 11 were asymptomatic. DNA dilution series $\mathrm{G} 4_{\mathrm{S}}$ and $\mathrm{P} 4_{S}$ in each of two different plates were used in these real-time qPCR assays, with two replications per each DNA sample.

DNA from opium poppy plants or seeds was diluted $1 / 2$ - or $1 / 5$ fold in SUW to reach a DNA concentration within a range similar to that used in the DNA dilution series. Then, plant DNA samples

Table 1. Sources of Peronospora arborescens and Papaver somniferum DNA used to develop the DNA dilution series used in this study

\begin{tabular}{|c|c|c|c|c|c|}
\hline \multirow[b]{2}{*}{ Source of DNA ${ }^{b}$} & \multicolumn{5}{|c|}{ DNA dilution series ${ }^{\mathbf{a}}$} \\
\hline & 1 & 2 & 3 & 4 & 5 \\
\hline \multicolumn{6}{|c|}{ Peronospora arborescens } \\
\hline Genomic & $\begin{array}{l}\text { Fresh DNA extracted } \\
\text { from frozen }\left(-80^{\circ} \mathrm{C}\right) \\
\text { mycelium and } \\
\text { sporangia, specimen } \\
\text { P98CSJ-2004, "Casilla } \\
\text { San José" Écija, } \\
\text { Sevilla, Spain }\end{array}$ & $\begin{array}{l}\text { Fresh DNA extracted } \\
\text { from fresh mycelium } \\
\text { and sporangia, } \\
\text { specimen C79CHO- } \\
\text { 2008, "Ruidero" Écija, } \\
\text { Sevilla, Spain }\end{array}$ & $\begin{array}{l}\text { Frozen }\left(-20^{\circ} \mathrm{C}\right) \text { DNA } \\
\text { from mycelium and } \\
\text { sporangia, specimen } \\
\text { C85EX-2007, growth } \\
\text { chamber experiments }\end{array}$ & $\begin{array}{l}\text { Fresh DNA extracted } \\
\text { from fresh mycelium } \\
\text { and sporangia, } \\
\text { specimen C168EX- } \\
\text { 2008, growth chamber } \\
\text { experiments }\end{array}$ & $\begin{array}{l}\text { Frost }\left(-20^{\circ} \mathrm{C}\right) / \text { defrost } \\
\left(20^{\circ} \mathrm{C}\right)(\times 5 \text { times }) \\
\text { DNA from specimen } \\
\text { C85EX-2007 from } \\
\text { series } 3\end{array}$ \\
\hline Plasmid & $\begin{array}{l}\text { Fresh DNA extracted } \\
\text { from clone } \\
\text { EC3_P38ESJ in June } \\
2008\end{array}$ & $\begin{array}{l}\text { Frozen }\left(-20^{\circ} \mathrm{C}\right) \\
\text { plasmid DNA from } \\
\text { series } 1\end{array}$ & $\begin{array}{l}\text { Fresh DNA extracted } \\
\text { from clone } \\
\text { EC3_P38ESJ in } \\
\text { September } 2008\end{array}$ & $\begin{array}{l}\text { Frozen }\left(-20^{\circ} \mathrm{C}\right) \\
\text { plasmid DNA from } \\
\text { series } 3\end{array}$ & $\begin{array}{l}\text { Frost }\left(-20^{\circ} \mathrm{C}\right) / \text { defrost } \\
\left(20^{\circ} \mathrm{C}\right)(\times 10 \text { times }) \\
\text { plasmid DNA from } \\
\text { series 1 }\end{array}$ \\
\hline \multicolumn{6}{|c|}{ Papaver somniferum cv. Nigrum } \\
\hline Leaves & $\begin{array}{l}\text { Fresh DNA extracted } \\
\text { from leaves of seedling } \\
\text { germinated in petri } \\
\text { dishes, seed stock L1 }\end{array}$ & $\begin{array}{l}\text { Frozen }\left(-20^{\circ} \mathrm{C}\right) \mathrm{DNA} \\
\text { from series } 1 \text { seedlings }\end{array}$ & $\begin{array}{l}\text { Fresh DNA extracted } \\
\text { from mature leaves of } \\
\text { plants in growth } \\
\text { chamber experiments, } \\
\text { seed stock L2 }\end{array}$ & $\begin{array}{l}\text { Frozen }\left(-20^{\circ} \mathrm{C}\right) \text { DNA } \\
\text { from series } 3 \text { mature } \\
\text { leaves }\end{array}$ & $\begin{array}{l}\text { Frost }\left(-20^{\circ} \mathrm{C}\right) / \text { defrost } \\
\left(20^{\circ} \mathrm{C}\right)(\times 10 \text { times }) \\
\text { plasmid DNA from } \\
\text { series 1 }\end{array}$ \\
\hline Seeds & $\begin{array}{l}\text { Fresh DNA extracted } \\
\text { in June } 2008 \text { from } \\
\text { commercial seed stock } \\
\text { S2-2007, ALCALIBER } \\
\text { S.A.c }\end{array}$ & $\begin{array}{l}\text { Fresh DNA extracted } \\
\text { in September } 2008 \\
\text { from commercial seed } \\
\text { stock S2-2007, } \\
\text { ALCALIBER S.A. }\end{array}$ & $\begin{array}{l}\text { Frozen }\left(-20^{\circ} \mathrm{C}\right) \text { DNA } \\
\text { from seed stock D200 } \\
\text { from growth chamber } \\
\text { experiment, } 2007\end{array}$ & $\begin{array}{l}\text { Frozen }\left(-20^{\circ} \mathrm{C}\right) \text { DNA } \\
\text { from seed stock D205 } \\
\text { from growth chamber } \\
\text { experiment, } 2007\end{array}$ & $\begin{array}{l}\text { Frost }\left(-20^{\circ} \mathrm{C}\right) / \text { defrost } \\
\left(20^{\circ} \mathrm{C}\right)(\times 10 \text { times }) \\
\text { DNA from seed stock } \\
\text { D205 from growth } \\
\text { chamber experiment, } \\
2007\end{array}$ \\
\hline
\end{tabular}

\footnotetext{
${ }^{a}$ Five DNA dilution series were obtained from 10-fold dilutions $\left[1: 1,1: 10,1: 10^{2}, 1: 10^{3}, 1: 10^{4}, 1: 10^{5}\right.$, and 1:10 $]$ of $P$. arborescens genomic DNA (1 ng/ $\mu$ l) or of plasmid DNA ( $1 \mathrm{ng} / \mu \mathrm{l}$; equivalent to $2.165 \times 10^{8}$ copies/ $\mu \mathrm{l}$ ) in sterile ultrapure water (SUW) (DNA dilution series $\mathrm{G}_{\mathrm{W}}$ and $\mathrm{P}_{\mathrm{W}}$ ) as well as in a fixed background of Papaver somniferum DNA $(40 \mathrm{ng} / \mu \mathrm{l})$ extracted from healthy opium poppy leaves (DNA dilution series $\mathrm{G}_{\mathrm{L}}$ and $\mathrm{P}_{\mathrm{L}}$ ) or seeds $(\mathrm{DNA}$ dilution series $\mathrm{G}_{\mathrm{S}}$ and $\mathrm{P}_{\mathrm{S}}$ ).

${ }^{\mathrm{b}}$ Plant growth conditions in growth chamber, $P$. arborescens inoculum obtention, and genomic DNA extraction of $P$. arborescens and opium poppy seeds and leaves have been described before $(27,34)$. Genomic DNA was extracted using the 'G-SpinTM IIp Plant Genomic DNA Extraction Kit' (Intron Biotechnology, Suwon, Korea) and the Fast Prep System Bio 101 (Qbiogene, Madrid, Spain) according to Landa et al. (27). plasmid DNA from Escherichia coli strain JM109 was extracted with QuickGene Plasmid Kit using the QuickGene-Mini80 device (Fujifilm Corporation, Tokyo, Japan) according to the manufacturer's instructions.

${ }^{c}$ ALCALIBER, S.A. (Carmona, Sevilla, Spain) is the only enterprise in Spain officially authorized for opium poppy cultivation and alkaloids extraction for pharmaceutical use.
} 
were accurately quantified in triplicate as described above and used to normalize $P$. arborescens DNA to total plant DNA present in each reaction. Results from real-time qPCR assays of unknown (seeds and stems) samples were compared to those obtained previously with simple- and nested-PCR assays using primer set P6 (33). Finally, the amount of pathogen DNA in unknown samples was estimated from the universal G-series regression lines once it was proven that $\mathrm{P} 4_{\mathrm{S}}$ standard regression lines did not differ statistically $(P \geq 0.05)$ from universal $\mathrm{P}$-series regression lines.

Data analyses. The cycle threshold $\left(\mathrm{C}_{\mathrm{T}}\right)$ values for each reaction were calculated first by determining the PCR cycle number at which the fluorescence signal exceeded background, using the default estimation criteria in the iCycler IQ software version 3.0a (Bio-Rad). Then, to appropriately compare and establish relationships between different DNA dilution series generated from different treatments, the threshold position was manually defined and fixed at the same position for all treatments and experiments (45).

Linear regressions of the natural logarithm of known concentrations of the target DNA versus the $\mathrm{C}_{\mathrm{T}}$ values were performed for each DNA dilution series by using Statistix 9.0 (Analytical Software, Tallahassee, FL). Standard regression lines from each plate chosen as reference curves were used for transforming the experimental $C_{T}$ values into amounts of pathogen DNA (nanograms) or copy numbers (plasmid). Statistical differences in $\mathrm{C}_{\mathrm{T}}$ and amplification efficiency (AE) between and among standard regression lines obtained for Gcurves and P-curves in different backgrounds were determined by one-way analysis of variance (ANOVA). Also, all standard regression lines obtained for $P$. arborescens genomic DNA (G-curves) and plasmid DNA (P-curves) in different backgrounds (W, L, and S), thermal cyclers, or using different qPCR reagents were statistically compared for homogeneity $(P \geq 0.05)$ of variance (Bartlett's test) and for equality of slopes and intercepts using an $F$ test at $P<0.05$. AE was calculated from the slopes of the standard regression curves using the equation $\mathrm{AE}=10^{(1 / \mathrm{slope})}-1(1,19)$.

\section{Results}

Optimization of the real-time qPCR assay. Reducing the standard reaction volume from 50 to $20 \mu \mathrm{l}$ had no effect on the accuracy of the real-time qPCR assay (data not shown). Consequently, a final volume of $20 \mu \mathrm{l}$ was chosen to minimize the cost per assay.
The optimized PCR reaction mixture was similar for each primer set and consisted of (final volume of $20 \mu \mathrm{l}$ ): $1 \mu \mathrm{l}$ of DNA sample, $1 \times$ iQ SYBR Green Supermix (BioRad), and $0.3 \mu \mathrm{M}$ of each primer. The thermal cycling conditions consisted of an initial denaturation at $95^{\circ} \mathrm{C}$ for 2 min followed by 35 cycles of 1 min at $95^{\circ} \mathrm{C}$, $1 \mathrm{~min}$ at $63^{\circ} \mathrm{C}, 1 \mathrm{~min}$ at $72^{\circ} \mathrm{C}$, and $83^{\circ} \mathrm{C}$ for $15 \mathrm{~s}$. A final extension step at $72^{\circ} \mathrm{C}$ for $10 \mathrm{~min}$ was added. Fluorescence of the target amplicon was detected at $83^{\circ} \mathrm{C}$. A threshold position of $400 \mathrm{RFU}$ (Relative Fluorescence Units) was fixed for all experiments to determine $C_{T}$ values (11) after appropriate validation. This allowed us to compare independent plates and pool results that showed statistical similarity $(P \geq 0.05)$. That position was chosen on the basis of establishing a compromise between detection of the $\mathrm{C}_{\mathrm{T}} \mathrm{s}$ in the exponential phase of the reaction and avoidance of background fluorescence $(11,45)$. No fluorescence of the target amplicon occurred for negative controls using any of the three primer sets or for $P$. cristata DNA (data not shown).

After optimizing real-time $\mathrm{qPCR}$ assays, standard regression lines were generated for each primer set using a range of DNA from $10 \mathrm{ng}$ to $100 \mathrm{fg}$. The highest reproducibility of amplifications was obtained with primer set P6, with a high efficiency measured over six orders of magnitude of DNA concentration, exhibiting a linear dynamic range of amplification. Standard regression lines obtained for primer set P6 indicated highly reproducible amplifications, better efficiencies, and higher coefficient of determination values ( $\mathrm{AE}=90.6$ to $100.3 \% ; R^{2}=0.990$ to 0.992 ) compared with those for primer sets $\mathrm{P} 2\left(\mathrm{AE}=92.2\right.$ to $112.3 \% ; R^{2}=0.778$ to $0.955)$ and $\mathrm{P} 3\left(\mathrm{AE}=83.3\right.$ to $107.8 \% ; R^{2}=0.979$ to 0.980$)$. Consequently, primer set P6 was chosen for subsequent experiments. Also, AE values larger than $100 \%$ were less frequent for primer set P6 (they occurred in less than $10 \%$ of all assays performed) compared with those obtained using primer sets $\mathrm{P} 2$ and $\mathrm{P} 3$, which may indicate PCR inhibition. In those cases, however, we got amplification when pathogen DNA was spiked in each sample that failed to amplify using the qPCR assay.

Real-time quantitative PCR reproducibility, efficiency, and sensitivity. The efficiency and reproducibility of real-time qPCR assays of G- and P-series standard regression lines were positively influenced by presence of the host DNA (i.e., leaf and seed tissues). Thus, for G-DNA dilution series, the accuracy (SD and $R^{2}$ )

Table 2. Sensitivity of Peronospora arborescens-specific primers used in simple- and nested-polymerase chain reaction (PCR) assays, as well as in the newly developed quantitative-PCR (qPCR) protocols with purified DNA of $P$. arborescens singly or mixed with host DNA

\begin{tabular}{|c|c|c|c|c|c|c|c|c|c|c|}
\hline \multirow{2}{*}{$\begin{array}{l}\text { PCR } \\
\text { protocol }^{b}\end{array}$} & \multirow{2}{*}{$\begin{array}{c}\text { DNA } \\
\text { DS }^{c}\end{array}$} & \multirow{2}{*}{$\begin{array}{c}\text { DNA } \\
\text { background } \\
(\mathrm{ng} / \mu \mathrm{l})^{\mathrm{c}}\end{array}$} & \multicolumn{7}{|c|}{ DNA of Peronospora arborescens $(\mathrm{pg} / \mu \mathrm{l})^{\mathrm{a}}$} & \multirow{2}{*}{$\begin{array}{c}\text { Negative } \\
\text { control }\end{array}$} \\
\hline & & & 1,000 & 100 & 10 & 1 & 0.1 & 0.01 & 0.001 & \\
\hline Simple & $\begin{array}{l}\mathrm{G}_{\mathrm{W}} \\
\mathrm{G}_{\mathrm{L}} \\
\mathrm{G}_{\mathrm{S}}\end{array}$ & $\begin{array}{r}0 \\
40 \\
40\end{array}$ & $\begin{array}{l}+/+^{\mathrm{c}} \\
+/+ \\
+/+\end{array}$ & $\begin{array}{l}+/+ \\
+/+ \\
+/+\end{array}$ & $\begin{array}{l} \pm / \pm \\
+/+ \\
+/+\end{array}$ & $\begin{array}{l}-1- \\
+/ \pm \\
\pm / \pm\end{array}$ & $\begin{array}{l}-1- \\
-1- \\
-1-\end{array}$ & $\begin{array}{l}-1- \\
-1- \\
-1-\end{array}$ & $\begin{array}{l}\mathrm{np} \\
\mathrm{np} \\
\mathrm{np}\end{array}$ & $\begin{array}{l}-1- \\
-1- \\
-1-\end{array}$ \\
\hline Quantitative & $\begin{array}{c}\mathrm{G}_{\mathrm{W}} \\
\mathrm{G}_{\mathrm{L}} \\
\mathrm{G}_{\mathrm{S}} \\
\mathrm{P}_{\mathrm{W}} \\
\mathrm{P}_{\mathrm{L}} \\
\mathrm{P}_{\mathrm{S}}\end{array}$ & $\begin{array}{r}0 \\
40 \\
40\end{array}$ & $\begin{array}{c}+/+ \\
16.1 \pm 0.8 \\
+/+ \\
14.8 \pm 0.3 \\
+/+ \\
14.8 \pm 0.3 \\
+/+ \\
11.1 \pm 0.3 \\
+/+ \\
11.4 \pm 0.3 \\
+/+ \\
11.6 \pm 0.3\end{array}$ & $\begin{array}{c}+/+ \\
18.8 \pm 0.5 \\
+/+ \\
17.9 \pm 0.5 \\
+/+ \\
17.9 \pm 0.4 \\
+/+ \\
12.3 \pm 0.4 \\
+/+ \\
14.4 \pm 0.5 \\
+/+ \\
14.3 \pm 0.3\end{array}$ & $\begin{array}{c}+/+ \\
22.8 \pm 0.6 \\
+/+ \\
21.6 \pm 0.5 \\
+/+ \\
21.5 \pm 0.4 \\
+/+ \\
15.6 \pm 0.9 \\
+/+ \\
17.2 \pm 0.4 \\
+/+ \\
17.4 \pm 0.2\end{array}$ & $\begin{array}{c} \pm /- \\
26.7 \pm 0.7 \\
+/+ \\
25.0 \pm 0.4 \\
+/+ \\
24.8 \pm 0.5 \\
+/+ \\
19.5 \pm 1.1 \\
+/+ \\
20.2 \pm 0.3 \\
+/+ \\
19.8 \pm 0.3\end{array}$ & $\begin{array}{c} \pm /- \\
30.6 \pm 0.8 \\
+/+ \\
28.5 \pm 0.6 \\
+/+ \\
28.5 \pm 0.6 \\
+/+ \\
23.2 \pm 1.1 \\
+/ \pm \\
23.3 \pm 0.5 \\
+/+ \\
23.0 \pm 0.4\end{array}$ & $\begin{array}{c}-/- \\
>35 \\
\pm / \pm \\
31.9 \pm 0.4 \\
\pm / \pm \\
31.6 \pm 0.2 \\
\pm /- \\
27.1 \pm 1.9 \\
+/+ \\
26.7 \pm 0.4 \\
+/+ \\
26.5 \pm 0.4\end{array}$ & $\begin{array}{c}-/- \\
\text { na } \\
-/- \\
>35 \\
-/- \\
>35 \\
-/- \\
30.8 \pm 1.5 \\
\pm /- \\
30.7 \pm 0.4 \\
\pm /- \\
30.6 \pm 0.5\end{array}$ & $\begin{array}{c}-l- \\
\text { na } \\
-l- \\
\text { na } \\
-l- \\
\text { na } \\
-l- \\
\text { na } \\
-l- \\
\text { na } \\
-l- \\
\text { na }\end{array}$ \\
\hline Nested & $\begin{array}{l}\mathrm{G}_{\mathrm{W}} \\
\mathrm{G}_{\mathrm{L}} \\
\mathrm{G}_{\mathrm{S}}\end{array}$ & $\begin{array}{r}0 \\
40 \\
40\end{array}$ & $\begin{array}{l}+/+ \\
+/+ \\
+/+\end{array}$ & $\begin{array}{l}+/+ \\
+/+ \\
+/+\end{array}$ & $\begin{array}{l}+/+ \\
+/+ \\
+/+\end{array}$ & $\begin{array}{l}+/+ \\
+/+ \\
+/+\end{array}$ & $\begin{array}{l}+/ \pm \\
+/+ \\
+/+\end{array}$ & $\begin{array}{l}+/ \pm \\
+/+ \\
+/+\end{array}$ & $\begin{array}{l}-/ \pm \\
+/+ \\
+/+\end{array}$ & $\begin{array}{l}-1- \\
-1- \\
-1-\end{array}$ \\
\hline
\end{tabular}

${ }^{a}$ Results were obtained for two series and by two independent operators with the same DNA dilution series. $+=$ positive amplification; $\pm=$ positive weak amplification; $-=$ no signal; na = no amplification (i.e., cycle threshold $\left[\mathrm{C}_{\mathrm{T}}\right]$ values were under a threshold fluorescence value of 400 ); np $=$ not performed. Numbers shown in the quantitative PCR assays correspond to eight $\mathrm{C}_{\mathrm{T}}$ values $\pm \mathrm{SD}$.

${ }^{\mathrm{b}}$ Primers OMPac7fw/OMPac7rv (set P6) were used in simple- and nested-PCR protocols as previously described (27,33) or in a quantitative PCR assay (this study).

${ }^{\text {c }}$ Six DNA dilution series (DS) were obtained by serially diluting $P$. arborescens DNA (1 ng/ $\mu \mathrm{l}$; G-series) or plasmid EC3_P38ESJ DNA (1 ng/ $\mu$; P-series) containing the internal transcribed spacer (ITS) region of the pathogen, to obtain from 1 ng to 1 fg of DNA per qPCR reaction. $P$. arborescens or plasmid DNA was diluted in sterile distilled water $\left(\mathrm{G}_{\mathrm{W}}\right.$ and $\left.\mathrm{P}_{\mathrm{W}}\right)$ or in Papaver somniferum DNA extracted from leaves $\left(\mathrm{G}_{\mathrm{L}}\right.$ and $\left.\mathrm{P}_{\mathrm{L}}\right)$ or from seeds $\left(\mathrm{G}_{\mathrm{L}}\right.$ and $\left.\mathrm{P}_{\mathrm{L}}\right)$. 
and amplification efficiency (AE) of real-time PCR assays was higher $\left(0.2<\mathrm{SD}<0.6 ; R^{2}>0.993\right.$; $\mathrm{AE}=93.0$ to $\left.93.1 \%\right)$ when $P$. arborescens DNA was diluted in leaf $\left(\mathrm{G}_{\mathrm{L}}\right)$ or seed $\left(\mathrm{G}_{\mathrm{S}}\right)$ DNA compared with that when DNA was diluted in water $\left(\mathrm{G}_{\mathrm{W}}\right)(0.5<\mathrm{SD}<$ $0.8 ; R^{2}=0.978 ; \mathrm{AE}=90.5 \%$ ) (Table 2 ; Fig. $1 \mathrm{~A}$ ). Statistical comparisons of the three standard regression lines indicated significant differences among intercepts $(P<0.0001)$ but not among slopes $(P$ $=0.7664)$. The intercept of the $\mathrm{G}_{\mathrm{W}}$ standard regression line was significantly higher than that of $\mathrm{G}_{\mathrm{L}}$ and $\mathrm{G}_{\mathrm{S}}$ standard regression lines, which indicate lower sensitivity of the former. Thus, $P$. arborescens DNA was not accurately quantified (high $\mathrm{SD}$ or $\mathrm{C}_{\mathrm{T}}>35$ ) at concentrations lower than $1 \mathrm{pg}$ if diluted in water $\left(\mathrm{G}_{\mathrm{W}}\right.$ series), but could be quantified up to $0.1 \mathrm{pg}$ when diluted in host leaf or seed DNA (Table 2; Fig. 1A).

As found for G-series, the $\mathrm{P}_{\mathrm{W}}$ standard regression lines showed lower AE and reproducibility of amplifications $\left(0.3<\mathrm{SD}<1.9 ; R^{2}\right.$ $>0.964$; $\mathrm{AE}>96.1 \%$ ) compared with $\mathrm{P}_{\mathrm{L}}$ and $\mathrm{P}_{\mathrm{S}}$ standard regression lines $\left(0.2<\mathrm{SD}<0.5 ; R^{2}>0.990 ; \mathrm{AE}=109.1\right.$ to $\left.110.2 \%\right)$. Both the slope and intercept of the $\mathrm{P}_{\mathrm{W}}$ standard regression line differed significantly $(P<0.001)$ from those of $\mathrm{P}_{\mathrm{L}}$ and $\mathrm{P}_{\mathrm{S}}$ regression lines. No significant differences $(P \geq 0.05)$ occurred between $\mathrm{P}_{\mathrm{L}}$ and $\mathrm{P}_{\mathrm{S}}$ standard regression lines (Table 2; Fig. 1B). Since use of host DNA background provided highly reproducible results, and $\mathrm{AE}$ values were within those ideal for real-time qPCR assays, we chose to use $G_{L}, G_{S}, P_{L}$, and $P_{S}$ DNA dilution series for subsequent experiments.

The detection limit of the real-time qPCR assay using $P$. arborescens DNA diluted in SUW ( $\mathrm{G}_{\mathrm{W}}$ series) was greater than that using host leaf DNA $\left(\mathrm{G}_{\mathrm{L}}\right.$ series) or seed DNA $\left(\mathrm{G}_{\mathrm{S}}\right.$ series $)$. Thus, there was a trend for increased detection and sensitivity when host DNA was present in the amplification reaction (Table 2). The detection limit of real-time qPCR was $0.1 \mathrm{pg}$ of $P$. arborescens DNA for $\mathrm{G} 1-2_{\mathrm{W}}$ and $0.01 \mathrm{pg}$ for $\mathrm{G} 1-2_{\mathrm{S}, \mathrm{L}}$ dilution series, as determined by the fluorescence signal of the amplicon. However, the amplified DNA band was scarcely discernable by gel electrophoresis at those concentrations of pathogen DNA (Table 2). For plasmid DNA (clone EC3_P38ESJ) P1-2 ${ }_{\mathrm{W}, \mathrm{S}, \mathrm{L}}$ dilution series, the detection limit for the real-time qPCR assay was $1 \mathrm{fg}$ of plasmid DNA (approximately 216.5 copies of a 1,200-bp insert), although $\mathrm{P}_{\mathrm{W}}$ dilution series showed less reproducible results $(\mathrm{SD}>1.9$ ) (Table 2). Use of the real-time qPCR detection protocol with different DNA dilution series or by different operators did not influence reproducibility and consistency of results (Table 2).

Development of a universal model for quantifying $P$. arborescens DNA in opium poppy tissues. The newly developed realtime qPCR protocol was highly reproducible and precise, as indicated by one-way ANOVA of $\mathrm{C}_{\mathrm{T}}$ values derived from 10 experiments for each of G- or P-series (five different DNA dilution series [Table 1] each processed twice by independent operators). There was homogeneity of variances $(P \geq 0.05)$ and neither the origin of the DNA sample $(P=0.9990$ and $P=0.9724$ for $\mathrm{G}$ - or P-series, respectively) nor operators $(P=0.9759$ and $P=0.9467$ for $\mathrm{G}$ - or $\mathrm{P}$ series, respectively) or background DNA (L and $\mathrm{S})(P=0.7934$ and $P=0.8558$ for $\mathrm{G}$ - or $\mathrm{P}$-series, respectively) significantly influenced results of real-time qPCR assays. All standard regression lines indicated high efficiency and reproducibility of amplifications, with $\mathrm{AE}$ values ranging from 89.6 to $99.6 \%$ for G-series and 95.7 to $111.1 \%$ for P-series, and standard deviations of $\mathrm{C}_{\mathrm{T}} \mathrm{s}$ lower than 0.5 in nearly all cases (Fig. 2A). Also, comparison of the 10 standard regression lines for each of G- or P- showed no significant differences among slopes $(P=0.3243$ and $P=0.1962$ for G-series and P-series, respectively) and intercepts $(P=0.0998$ and $P=$ 0.3366 for G-series and P-series, respectively) (Fig. 2B and C). Consequently, to obtain a robust and universal regression model, the 10 series of real-time qPCR data obtained for each G- or PDNA dilution series were pooled and fitted to a simple regression model for each (Fig. 2B and C), i.e., G-standard regression model and $\mathrm{P}$-standard regression model, respectively.

The real-time qPCR protocol was validated in different laboratories using different equipments and $\mathrm{qPCR}$ reagents. Comparison of the standard regression lines for each of $\mathrm{P} 4-5_{\mathrm{L}}$ dilution series indicated no significant differences among slopes $(P>0.2485)$ of regression lines when comparing different equipments or qPCR reagents, which indicates similar efficiency and reproducibility. However, that comparison indicated significant differences among intercepts $(P<0.001)$ due possibly to a lower sensitivity of the sensiMixPlus SYBR kit (Quantace) (data not shown).

Finally, the predicted $P$. arborescens DNA concentration estimated with the G-standard regression model was regressed against the predicted plasmid copy number estimated with the P-standard regression model for similar $\mathrm{C}_{\mathrm{T}}$ values. The resulting equation $\left[\log \left(\mathrm{DNA}_{\mathrm{G}}\right)=6,576-0,891 \times \log (\right.$ plasmid copy number $\left.)\right]$ can be used to estimate the pathogen concentration from the number of plasmid copies obtained from any qPCR assay.

Validation of the regression model and quantification of $P$. arborescens DNA in opium poppy tissues. Use of the real-time qPCR protocol allowed detection of $P$. arborescens DNA in $68.2 \%$ of stem samples from 22 asymptomatic opium poppy plants that were proved systemically infected with $P$. arborescens by nestedPCR assays in a previous work (Fig. 3; 34). However, use of that nested-PCR protocol did not allow quantifying the pathogen DNA

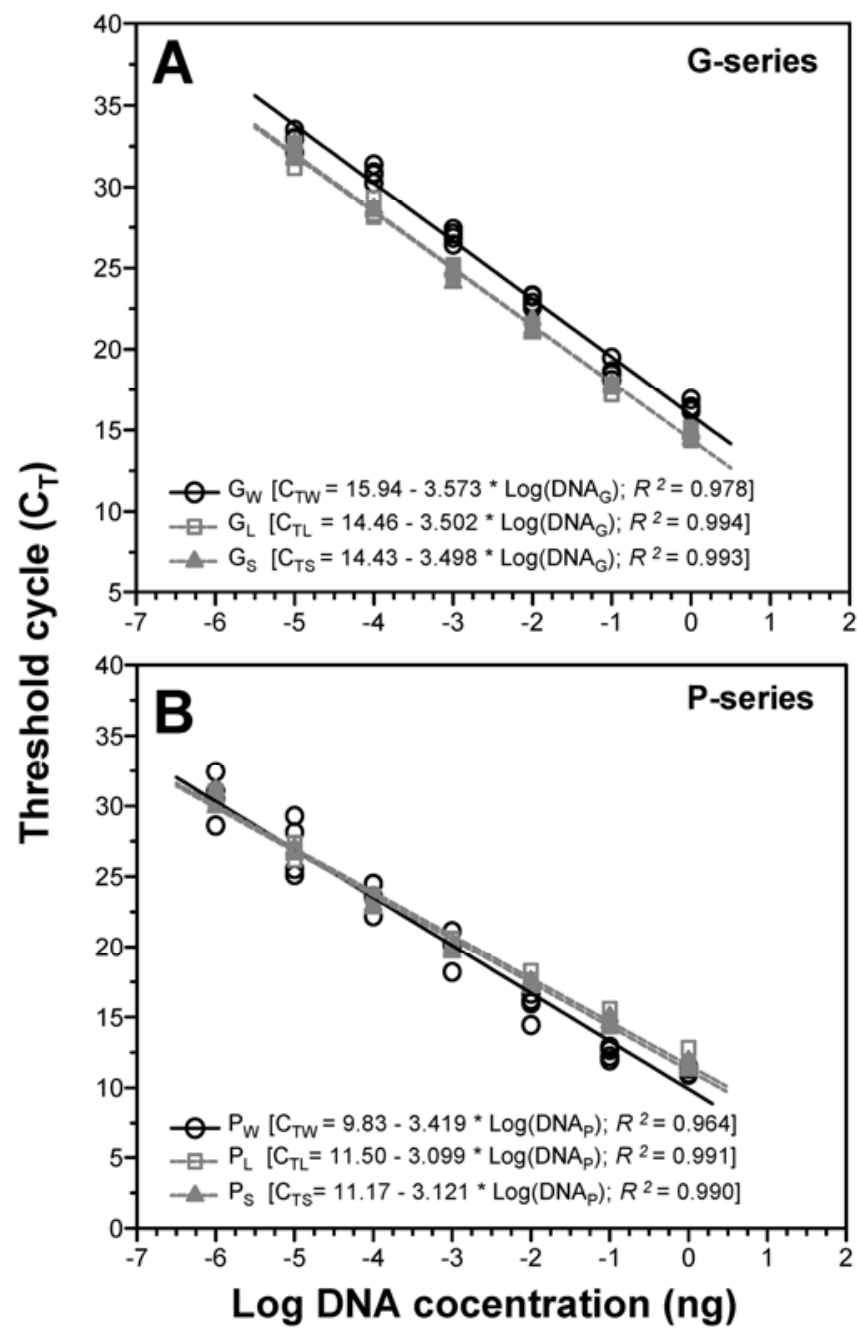

Fig. 1. Standard regression lines of (A) a five-point 10-fold serial dilution of Peronospora arborescens DNA (1 ng/ $\mathrm{\mu l}$; G-series) or (B) six-point 10-fold serial dilution of plasmid EC3_P38ESJ DNA (1 ng/ $\mu$; P-series) containing the internal transcribed spacer (ITS) region (a 1,200-bp insert) of the pathogen diluted in ultrapure sterile water $\left(G_{W}\right.$ and $\left.P_{W}\right)$ or in Papaver somniferum DNA (40 ng) extracted from leaves $\left(G_{L}\right.$ and $\left.P_{L}\right)$ or seeds $\left(G_{S}\right.$ and $\left.P_{S}\right)$. Threshold cycles $\left(C_{T}\right)$ were plotted against the log of genomic DNA standard curves of known concentrations. Data shown are from two different DNA standard curves and two independent operators. Each data point represents the mean of two quantitative polymerase chain reaction (qPCR) replications. 

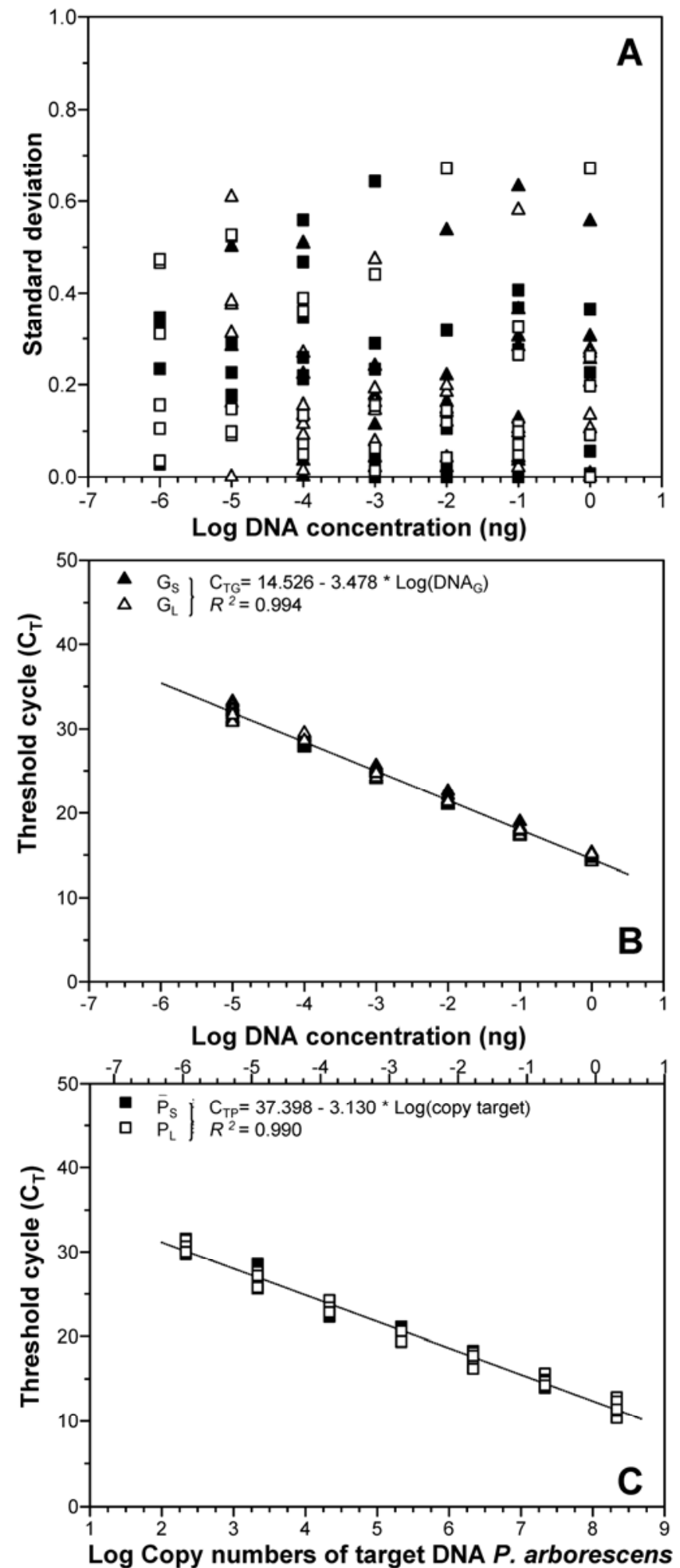

Fig. 2. Standard deviations (A) and standard regression lines of a five-point 10-fold serial dilution of Peronospora arborescens DNA (1 ng/ul; G-series), (B) or of a sixpoint 10-fold serial dilution of plasmid EC3_P38ESJ DNA (1 $\mathrm{ng} / \mu$ l equivalent to $2.165 \times 10^{8} \mathrm{copies} / \mu$; P-series) containing the internal transcribed spacer (ITS) region (1,200-bp insert) of the pathogen (C). Both $\mathrm{G}$ - and P-series were diluted in Papaver somniferum DNA (40 ng) extracted from leaves $\left(G_{L}\right.$ and $\left.P_{L}\right)$ or seeds $\left(G_{S}\right.$ and $P_{S}$ ). Threshold cycles $\left(C_{T}\right)$ were plotted against the log of genomic DNA of known concentrations $\left(G_{L}\right.$ and $\left.G_{S}\right)$ or against the log of plasmid copy numbers $\left(P_{L}\right.$ and $P_{S}$ ). Data shown are from five different DNA dilution series and two independent operators. Each data point represents the mean of two quantitative polymerase chain reaction (qPCR) replications. Upper scale in $\mathrm{C}$ panel corresponds to equivalent amount of plasmid DNA (ng). in those stem samples, which yielded a weak amplification (data not shown). Amount of $P$. arborescens DNA in DNA samples extracted from stems of asymptomatic plants was highly variable, ranging from $0.110 \mathrm{ppm}$ to $5,557 \mathrm{ppm}(5.6 \%$ ) (Fig. 3A) or its equivalence of 0.39 to $9,17 \times 10^{4}$ copy numbers of $P$. arborescens target DNA/ng of Papaver somniferum DNA (Fig. 3B).

Use of the real-time qPCR protocol allowed detecting $P$. arborescens DNA in $100 \%$ of commercial seed stocks and $97.0 \%$ of seed samples analyzed. Also, it allowed quantifying a pathogen biomass as low as $1.2 \mathrm{pg}$ of target DNA per microgram of seed DNA (i.e., $0.0013 \%$ of $P$. arborescens in Papaver somniferum DNA; or 7.05 copy numbers of $P$. arborescens target DNA/ng of Papaver somniferum DNA) (Fig. 4). The level of detection of the pathogen in seed samples by real-time qPCR assays correlated with that found in previous detection assays of those same seed samples using simple- or nested-PCR assays $(27,34)$. The quantity of $P$. arborescens DNA ranged from 0.074 to $0.0013 \%$ (Fig. 4A), 0.0004 to $0.091 \%$ (Fig. 4B), and 0.05 to $1.275 \%$ o (Fig. 4C) in seed samples that produced, respectively, null, weak, or positive amplifications in simple-PCR assay, and a weak, positive, or positive amplification, respectively, in nested-PCR assays. In highly infested seed stocks (e.g., number 923, Fig. 4C), P. arborescens comprised as much as $0.077 \%$ in Papaver somniferum DNA $(1,77$ $\times 10^{4}$ copy numbers of $P$. arborescens target DNA/ng of Papaver somniferum DNA), which represents approximately $0.256 \mathrm{mg}$ of $P$. arborescens DNA per kilogram of seed. The amount of the pathogen DNA within a seed stock varied among the three independent samples assayed, which indicates the necessity of performing several replicates per seed stock to obtain accurate pathogen quantification (Fig. 4).
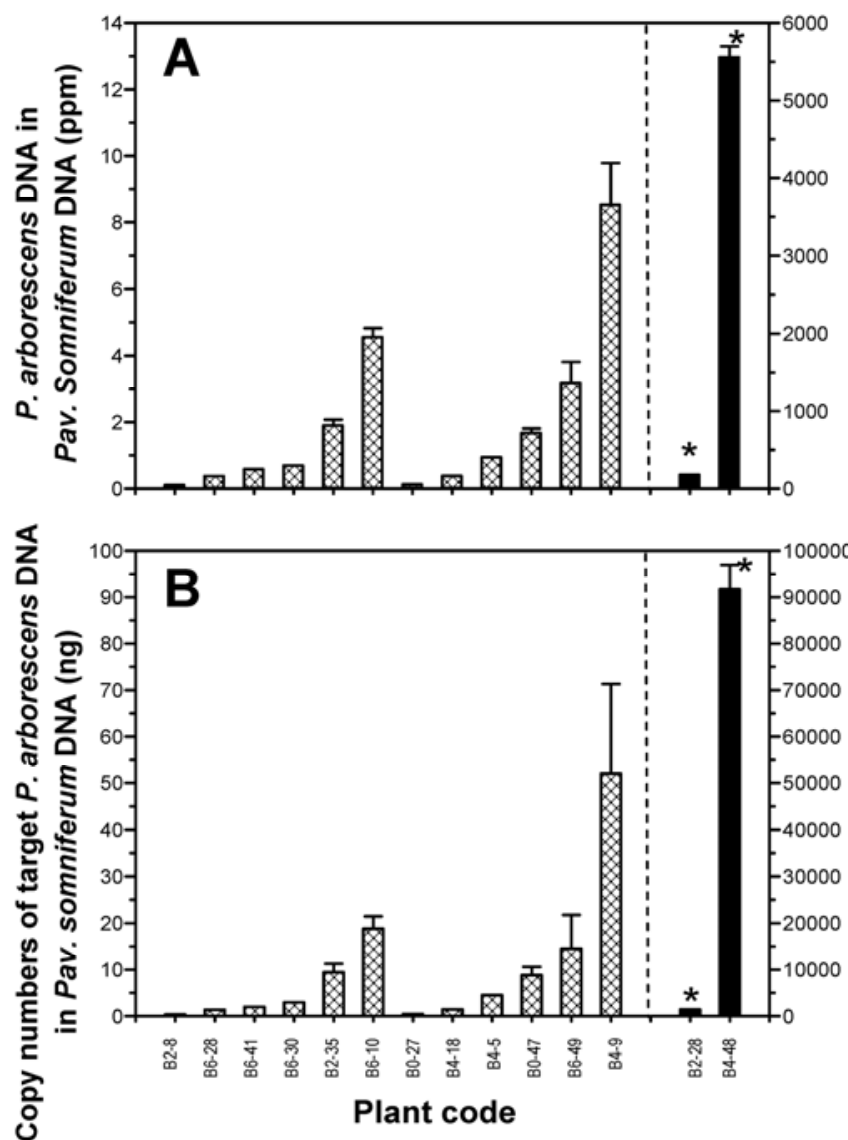

Fig. 3. Quantification of Peronospora arborescens DNA in stem of asymptomatically infected Papaver somniferum plants expressed as relative amounts of $P$. arborescens DNA in Papaver somniferum DNA (ppm) (A) or as $P$. arborescens copy numbers/Papaver somniferum DNA (B) quantified in each individual plant. Data shown are the mean of two quantitative polymerase chain reaction (qPCR) replications \pm standard deviation. $*=$ Scale for the two stem samples is on right $Y$-axis. 
Finally, real-time qPCR assays of seeds harvested from 30 individual poppy capsules from the field (of which 11 were asymptomatic, six affected with mild downy mildew symptoms, and 13 had evident pathogen sporulation) allowed detection of $P$. arborescens in $70.0 \%(21 / 30)$ of all samples assayed and $36.4 \%$ (4/11) of asymptomatic capsules. In seeds from asymptomatic capsules that were positive for the pathogen quantification, P. arborescens was 0.0003 to $0.007 \%$ in Papaver somniferum DNA or as low as 1.25 to 748.0 copy numbers of $P$. arborescens target DNA/ng of Papaver somniferum DNA. On the other hand, $P$. arborescens in symptomatic capsules was 0.006 to $0.61 \%$ (capsules with mild symptoms) or 0.12 to
$2.53 \%$ (capsules with pathogen sporulation) in Papaver somniferum DNA (data not shown).

\section{Discussion}

Several studies have developed real-time qPCR assays for identification and quantification of oomycetes, mainly Phytophthora and Pythium spp. $(4,6,7,24,38,40,42,47,48)$; however, to the best of our knowledge, only three studies have developed real-time qPCR protocols for the identification or quantification of the obligate biotroph Peronospora spp. causing downy mildew diseases $(9,21,46)$. Although species-specific PCR protocols are available for diagnosing either of the two downy mildew pathogens of opium
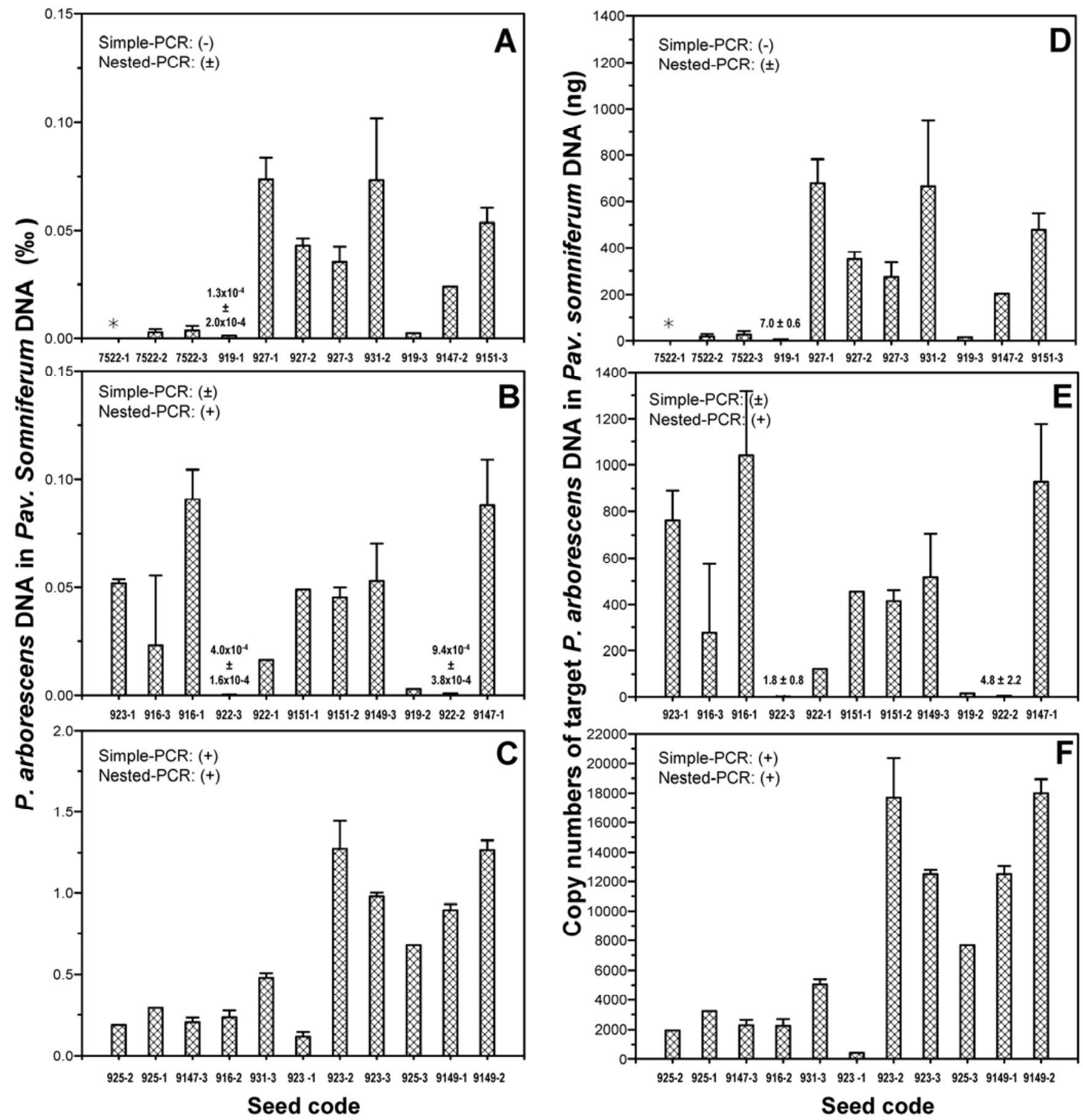

Fig. 4. Quantification of Peronospora arborescens DNA in commercial seed stock samples (300 mg) of Papaver somniferum expressed as relative amounts of $P$. arborescens DNA in Papaver somniferum DNA (\%) (A to C) or as P. arborescens copy numbers/Papaver somniferum DNA (D to F). Data shown are the mean of two quantitative polymerase chain reaction (qPCR) replications \pm standard deviation. $(+),( \pm)$, and (-) indicate positive, weak, or no amplification, respectively, after simple or nested-PCR assays using same DNA samples as shown in Montes-Borrego et al. (33). * = Sample was below detection limit of qPCR assay. Data shown are the mean of two independent PCR plates and two qPCR replications \pm standard deviation. 
poppy described in the literature, $P$. arborescens and $P$. cristata, none of them are quantitative in nature $(27,33,41)$.

One of the main objectives of our study was to provide ALCALIBER S.A. with a cost-viable technology in field studies on a practical basis that would allow better understanding of the biology of this pathogen and its interaction in the host plant. For absolute quantification in real-time qPCR assays, the accuracy of quantification of unknown samples depends entirely on the accuracy of the DNA dilution series $(45,49)$. In our study, we chose to use a fluorescent dye for quantifying the DNA employed in the DNA dilution series. The dye is highly selective for dsDNA over RNA, its fluorescence signal is not affected by many common contaminants, and it provides an increase in sensitivity extending the detection range significantly as compared to absorbance determination $(16,35,43)$. We believe that the measures for realistic estimates of plasmid and pathogen DNA concentrations taken in our study for developing the DNA dilution series was critical for the high reproducibility, precision and accuracy of results from the developed real-time qPCR assay. Accuracy was accomplished by quantifying each DNA sample with the Quant-iT DNA assay kit (Molecular Probes Inc.) in triplicate, in two independent microplates, and using internal controls of DNA quantification in each assay. Similar results may be obtained using other fluorescent intercalating DNA dyes and kits after appropriate adjustments (35). An additional advantage of the host DNA quantification in our protocol was that we were able to introduce a final normalization step in our assay. This was done by deriving the ratio of pathogen DNA (quantified by the real-time qPCR assay) to host DNA in each test sample (previously quantified by fluorescence), thus adjusting the variation introduced by sample to sample differences in DNA extraction. Furthermore, this avoided the cost of quantifying the host DNA by additional qPCR assays $(14,46,49)$.

In the newly developed protocol, the amplification efficiency (AE), sensitivity, and reproducibility of real-time qPCR assays of both G-series and P-series DNA standard regression lines were positively affected by presence of the host DNA from leaf and seed tissues. Thus, there was a trend for higher sensitivity when host DNA was present in the reaction as it had been shown previously for the simple- and nested-PCR protocols $(27,33)$. In other studies, either a reduction $(28,29,38,46)$ or no effect $(3,46)$ was found in $\mathrm{AE}$, accuracy, and detection limit when using a background DNA of host plant tissues in qPCR assays. However, the influence of host DNA in those parameters of the qPCR assay was not assessed in most studies $(21,38,40,42)$. It has been reported that the formation of primer-dimers is favored at low concentrations of target DNA, thus lowering the sensitivity and producing skews of the standard curves. Also, target DNA may adhere to the plastic ware so that addition of some host or foreign matrix DNA to the qPCR mix can minimize the loss of target DNA $(3,18,21)$.

Because experimental variation is likely to occur in studies like ours, it is important that results of qPCR assays are validated by measuring intra- and inter-assay variation. Most studies estimate that variation using $\mathrm{C}_{\mathrm{T}}$ values only. This may not be the most appropriate procedure for that purpose because $C_{T}$ values are logarithmic units and will misrepresent true variability (49). In this study, we statistically compared the two parameters (slopes and intercepts) of the standard regression lines obtained for both $P$. arborescens genomic and plasmid DNA dilution series, as well as for different backgrounds (leaf and seed DNA). A similar approach of validation procedure was recently used by Atallah et al. (3) and McNeil et al. (31) who compared one or two parameters of the regression line. In our research, statistical analysis of 10 DNA standard regression lines obtained using different plant and pathogen DNA sources indicated that neither the source of the DNA sample (fresh, frozen, etc.), the background DNA (leaf and seed DNA), nor the operator performing the experiment significantly influenced the results of the real-time qPCR assay, validating the robustness of the protocol developed. The results allowed establishing a numerical relationship between them. With regression equation models, data from experiments can be validated using only the plasmid DNA dilution series containing the $P$. arborescens target sequence, allowing the universal protocol to quantify $P$. $a r$ borescens in opium poppy tissues, since the plasmid DNA dilution series can be built and stored for a long time without losing accuracy in the quantification. More importantly, the plasmid DNA dilution series can be exchanged among different laboratories, facilitating the use of the real-time GPCR protocol on a large scale. We validated the reproducibility of the models by testing the plasmid DNA dilution series using different qPCR commercial kits and two different sets of equipment. Results indicated that there were only significant differences among intercepts but not among slopes of the regression lines, which implied that each qPCR reagent might have a different sensitivity.

While reviewing the literature on development of real-time qPCR protocols for quantifying plant pathogens in host tissues, we were unable to find examples of an optimization process as strict as that done in the present study that satisfied the MIQE guidelines (10) and allowed establishing universal regression equation models. In most studies, a simple or few experiments were performed for optimizing the real-time qPCR protocol developed, the information provided was scarce, and the results were derived from just a simple standard regression line for pathogen DNA diluted in water or host DNA in a unique laboratory or using a unique qPCR reagent. Possibly, as indicated by Bustin et al. (10), it would be worthwhile to start requesting that a MIQE guideline is satisfied in any $\mathrm{qPCR}$ published protocol that would ensure its relevance, accuracy, correct interpretation, and repeatability. Similar guidelines have been drawn up for DNA microarray analyses, proteomics experiments, and metabolomics (10), all of which are initiatives coordinated under the umbrella of MIBBI (Minimum Information for Biological and Biochemical Investigations, http://www. mibbi.org) (44). Certainly, in the absence of such standards for real-time $\mathrm{qPCR}$, it remains with authors to assure that experiments involving real-time qPCR are appropriately validated and that any conclusions are rigorously supported by the actual data, in order to be reproducible by other laboratories.

One of the main features of the real-time qPCR protocol here reported is its high sensitivity. It allowed us to readily detect up to $10 \mathrm{fg}$ of $P$. arborescens DNA in $40 \mathrm{ng}$ of host DNA without losing accuracy. This sensitivity is close to that of the nested-PCR ( $1 \mathrm{fg})$ protocol using the same primer set previously developed (33). Interestingly, the sensitivity of the qPCR protocol was higher than that reported for other qPCR assays, in which Taq Man probes, SYBR Green I, or scorpion primers were used for quantifying $P$. viticola on leaves of Vitis vinifera (46), four species of Phytophthora (Ph. ramorum, Ph. kernoviae, Ph. quercina, and Ph. citricola) in different plant species (38), P. sparsa in Rubus spp. (21), Alternaria brassicae in cruciferous seeds (15), Phytophthora capsici in pepper genotypes (42), Verticillium dahliae in potato lines (3), and Ph. nicotianae and Ph. citrophthora in citrus roots (24). This higher level of sensitivity of the newly developed qPCR protocol may be due to primer set P6 being developed from the ITS regions of the rDNA that occur in multicopies (e.g., $414 \pm 12$ copies per haploid genome in Ph. infestans) (25). Nevertheless, some of the studies mentioned above used primers targeting the same gene $(24,42)$.

The main advantage of the high sensitivity of the new real-time qPCR protocol is that it allows detection and quantification of the pathogen biomass in complex, naturally infested samples from multiple origins, including seeds from asymptomatic capsules and commercial seed stocks, as well as from asymptomatic opium poppy plants systemically infected by $P$. arborescens. Downy mildews are among the most destructive diseases of crops worldwide and can be seedborne. Consequently, efforts should be made to avoid introduction of infected seeds into areas where the pathogens do not occur. Although the presence of different Peronospora spp. on commercial seed lots have been documented using specificPCR assays $(5,22)$, no studies have developed real-time qPCR assays to quantify Peronospora spp. on seeds as has been done for some plant-pathogenic fungi $(12,15,31)$. Recently, we demon- 
strated that $P$. arborescens can be seed transmitted (27) and that the pathogen can be detected in commercial seed stocks harvested from opium poppy crops that have either no evidence or low incidence of downy mildew (33). In this present research, we demonstrated that the quantity of $P$. arborescens DNA in commercial seed stocks can range from 0.0013 to $1.275 \%$ o in Papaver somniferum DNA, and amount to as much as $0.256 \mathrm{mg}$ of $P$. arborescens DNA per $\mathrm{kg}$ of seed. We also demonstrated that $P$. arborescens amounting up to $0.61 \%$ of Papaver somniferum DNA can be detected in seeds harvested from asymptomatic capsules. This fact is particularly important for companies officially authorized for opium poppy cultivation. It also may explain why the downy mildew pathogen has spread rapidly to large areas in this country where opium poppy had not been cropped before despite the seed stocks for the next year being selected from fields that showed no symptoms of disease. Studies are in progress to determine whether or not low inoculum levels of the pathogen on seeds, such as those quantified in asymptomatic capsules or capsules with mild symptoms, may give rise to a high incidence of downy mildew-infected plants.

In a previous work using a nested-PCR protocol (34), we demonstrated the occurrence of asymptomatic, systemic infections of plants grown under controlled conditions. More importantly, we verified that asymptomatic opium plants cv. Nigrum systemically infected by $P$. arborescens soilborne oospores or airborne sporangia can produce viable, infected seeds (34) as occur in other downy mildew pathosystems (e.g., Plasmopara halstedii/Helianthus annuus [13], and Peronospora ducometi/Fagopyrum sculentum [50]). Such results are of particular importance for establishing disease control strategies based on the use of pathogen-free seed stocks, since seeds harvested from asymptomatic plants have no guarantee of being free from infection as indicated by the spread of the opium poppy downy mildew pathogen in Spain. Moreover, in this study, we have quantified highly variable amounts of $P$. arborescens DNA in stem samples from asymptomatic plants that ranged from $0.110 \mathrm{ppm}$ to $5,557 \mathrm{ppm}(5.6 \%$ ). It would be worthwhile to determine if there is a relationship between the amount of $P$. arborescens DNA present in the stem of a symptomless plant and the eventual success of seed infection.

Only a few of the many real-time qPCR protocols developed for in planta quantification of plant pathogens reportedly have the ability to quantify the pathogen in asymptomatic or low diseaseseverity responses $(42,47)$. The feasibility to do so using the qPCR protocol developed in this study would be of much interest for downy mildew resistance screening of opium poppy germplasm. For example, use of the protocol allowed us to quantify $P$. arborescens DNA in asymptomatic systemic infections of opium poppy plants cv. Nigrum, despite this cultivar being considered moderately resistant to downy mildew (F. J. Muñoz-Ledesma, personal communication). Indeed, several opium poppy breeding lines and accessions have been identified by ALCALIBER S.A. that show no downy mildew symptoms under a high load of $P$. arborescens inoculum in the field. Consequently, determining whether the asymptomatic response found in that germplasm is due to resistance or tolerance to pathogen infection will be of great value for selecting breeding lines for further use in hybridizations.

In summary, we believe that the real-time qPCR protocol developed in this study for the identification and quantification of $P$. arborescens in opium poppy plant tissues and seed stocks will be of great use for studies aimed to gaining better understanding of downy mildew epidemiology and efficient management through disease prediction, risk assessment, disease resistance breeding, and efficacy assessment of disease control measures.

\section{Acknowledgments}

Financial support for this research was provided by grants PET2006_0444 from 'Ministerio de Educación y Ciencia' of Spain and the European Social Fund, and from an 'Intramural Project' to B. B. Landa from the Spanish Council for Research (CSIC) and from ALCALIBER I+D+i, S.L. We are grateful to F. J. Durán-Gutierrez and J. M. León-Ropero for excellent technical assistance and J. A. Navas-Cortés for suggestions on statistical analysis and critically reading the manuscript prior to submission. We also thank the Bio-Rad, Roche, and Quantace companies and their representatives in Spain for providing samples of the qPCR reagents for the study. Editorial improvement of the manuscript by anonymous reviewers and the Senior Editor is gratefully acknowledged.

\section{Literature Cited}

1. Adams, P. S. 2006. Data analysis and reporting. Pages 39-62 in: Real-Time PCR. M. Tevfik Dorak, ed. Taylor \& Francis, New York.

2. Aranda, S., Montes-Borrego, M., Muñoz-Ledesma, F. J., Jiménez-Díaz, R M., and Landa, B. B. 2008. First report of Pectobacterium carotovorum causing soft rot of opium poppy in Spain. Plant Dis. 92:317.

3. Atallah, Z. K., Bae, J., Jansky, S. H., Rouse, D. I., and Stevenson, W. R. 2007. Multiplex real-time quantitative PCR to detect and quantify Verticillium dahliae colonization in potato lines that differ in response to Verticillium wilt. Phytopathology 97:865-872

4. Atallah, Z. K., and Stevenson, W. R. 2006. A methodology to detect and quantify five pathogens causing potato tuber decay using real-time quantitative polymerase chain reaction. Phytopathology 96:1037-1045.

5. Belbahri, L., Calmin, G., Pawlowski, J., and Lefort, F. 2005. Phylogenetic analysis and real time PCR detection of a presumably undescribed Peronospora species on sweet basil and sage. Mycol. Res. 109:1276-1287.

6. Bilodeau, G. J., Lévesque, C. A., de Cock, A. W. A. M., Duchaine, C., Brière, S., Uribe, P., Martin, F. N., and Hamelin, R. C. 2007. Molecular detection of Phytophthora ramorum by real-time polymerase chain reaction using TaqMan, SYBR Green, and molecular beacons. Phytopathology 97:632-642.

7. Böhm, J., Hahn, A., Schubert, R., Bahnweg, G., Adler, N., Nechwatal, J., Oehlmann, R., and Oßwald, W. 1999. Real-time quantitative PCR: DNA determination in isolated spores of the mycorrhizal fungus Glomus mosseae and monitoring of Phytophthora infestans and Phytophthora citricola in their respective host plants. J. Phytopathol. 147:409-416.

8. Bonants, P., De Weerdt, M. H., Van Gent Pelzer, M., Lacourt, I., Cooke, D., and Duncan, J. 1997. Detection and identification of Phytophthora fragariae by the polymerase chain reaction. Eur. J. Plant Pathol. 103:345-355.

9. Brouwer, M., Lievens, B., Van Hemelrijck, W., Van den Ackerveken, G., Cammue, B. P. A., and Thomma, B. P. H. J. 2003. Quantification of disease progression of several microbial pathogens on Arabidopsis thaliana using real-time fluorescence PCR. FEMS Microbiol. Lett. 228:241-248.

10. Bustin, S. A., Benes, V., Garson, J. A., Hellemans, J., Huggett, J., Kubista, M., Mueller, R., Nolan, T., Pfaffl, M. W., Shipley, G. L., Vandesompele, J., and Wittwer, C. T. 2009. The MIQE Guidelines: Minimum Information for Publication of Quantitative Real-Time PCR Experiments. Clin. Chem. 55:611-622.

11. Bustin, S. A., and Nolan, T. 2004. Pitfalls of quantitative real-time reversetranscription polymerase chain reaction. J. Biomol. Technol. 15:155-166.

12. Chilvers, M. I., du Toit, L. J., Akamatsu, H., and Peever, T. L. 2007. A realtime, quantitative PCR seed assay for Botrytis spp. that cause neck rot of onion. Plant Dis. 91:599-608.

13. Cohen, Y., and Sackston, W. E. 1974. Seed infection and latent infection of sunflowers by Plasmopara halstedii. Can. J. Bot. 52:231-238.

14. Gachon, C., and Saindrenan, P. 2004. Real-time PCR monitoring of fungal development in Arabidopsis thaliana infected by Alternaria brassicicola and Botrytis cinerea. Plant Physiol. Biochem. 42:367-371.

15. Guillemette, T., Iacomi-Vasilescu, B., and Simoneau, P. 2004. Conventional and real-time PCR-based assay for detecting pathogenic Alternaria brassicae in cruciferous seed. Plant Dis. 88:490-496.

16. Haugland, R. P. 2005. The Handbook. A Guide to Fluorescent Probes and Labeling Technologies, 10th ed. Molecular Probes, Inc., Eugene, OR, USA.

17. Henson, J. M., and French, R. 1993 The polymerase chain reaction and plant disease diagnosis. Annu. Rev. Phytopathol. 31:81-109.

18. Heuser, T., and Zimmer, W. 2002. Quantitative analysis of phytopathogenic ascomycota on leaves of pedunculate oaks (Quercus robur L.) by real-time PCR. FEMS Microbiol. Lett. 209:295-299.

19. Higuchi, R., Fockler, C., Dollinger, G., and Watson, R. 1993. Kinetic PCR analysis: Real time monitoring of DNA amplification reactions. Biotechnology 11:1026-1030.

20. Hoagland, D. R., and Arnon, D. I. 1950. The water culture method for growing plants without soil. Calif. Agric. Exp. Stn. Circ. No. 347.

21. Hukkanen, A., Pietikäinen, L., Kärenlampi, S., and Kokko, H. 2006. Quantification of downy mildew (Peronospora sparsa) in Rubus species using real-time PCR. Eur. J. Plant Pathol. 116:225-235.

22. Inava, T., Takahashi, K., and Morinaka, T. 1983. Seed transmission of spinach downy mildew. Plant Dis. 67:1139-1141.

23. INCB (International Narcotics Control Board). 2006. Narcotic drugs. Estimated World Requirements for 2007. Statistics for 2005. New York (Vienna), UN.

24. Ippolito, A., Schena, L., Nigro, F., Ligorio, V.-S., and Yaseen, T. 2004. Realtime detection of Phytophthora nicotianae and P. citrophthora in citrus roots and soil. Eur. J. Plant Pathol. 110:833-843.

25. Judelson, H. S., and Randall, T. A. 1998. Families of repeated DNA in the oomycete Phytophthora infestans and their distribution within the genus. Genome 41:605-615.

26. Landa, B. B., Montes-Borrego, M., Muñoz-Ledesma, F. J., and JiménezDíaz, R. M. 2005. First report of downy mildew of opium poppy caused by 
Peronospora arborescens in Spain. Plant Dis. 89:338.

27. Landa, B. B., Montes-Borrego, M., Muñoz-Ledesma, F. J., and JiménezDíaz, R. M. 2007. Phylogenetic analysis of downy mildew pathogens of opium poppy and PCR-based in planta and seed detection of Peronospora arborescens. Phytopathology 97:1380-1390.

28. Li, W., Hartung, J. S., and Levy, L. 2007. Evaluation of DNA amplification methods for improved detection of "Candidatus Liberibacter species" associated with citrus huanglongbing. Plant Dis. 91:51-58.

29. Li, W., Li, D., Twieg, E., Hartung, J. S., and Levy, L. 2008. Optimized quantification of unculturable Candidatus Liberibacter spp. in host plants using real-time PCR. Plant Dis. 92:854-861.

30. Martin, R. R., James, D., and Lévesque, C. A. 2000. Impact of molecular diagnostic technologies on plant disease management. Annu. Rev. Phytopathol. 38:207-239.

31. McNeil, M., Roberts, A. M. I., Cockerell, V., and Mulholland, V. 2004. Real-time PCR assay for quantification of Tilletia caries contamination of UK wheat seed. Plant Pathol. 53:741-750.

32. Montes-Borrego, M., Muñoz-Ledesma, F. J., Jiménez-Díaz, R. M., and Landa, B. B. 2008. Downy mildew of commercial opium poppy crops in France is caused by Peronospora arborescens. Plant Dis. 92:834.

33. Montes-Borrego, M., Muñoz-Ledesma, F. J., Jiménez-Díaz, R. M., and Landa, B. B. 2009. A nested-PCR protocol for detection and population biology studies of Peronospora arborescens, the downy mildew pathogen of opium poppy, using herbarium specimens and asymptomatic, fresh plant tissues. Phytopathology 99:73-81.

34. Montes-Borrego, M., Navas-Cortés, J. A., Muñoz-Ledesma, F. J., JiménezDíaz, R. M., and Landa, B. B. 2009. Role of oospores as primary inoculum for epidemics of downy mildew caused by Peronospora arborescens in opium poppy crops in Spain. Plant Pathol. 58:1092-1103.

35. Rengarajan, K., Cristol, S. M., Mehta, M., and Nickerson, J. M. 2002. Quantifying DNA concentrations using fluorometry: A comparison of fluorophores. Mol. Vision 8:416-421.

36. Schaad, N. W., and Frederick, R. D. 2002. Real-time PCR and its application for rapid plant disease diagnostics. Can. J. Plant Pathol. 24:250-258.

37. Schaad, N. W., Frederick, R. D., Shaw, J., Schneider, W. L., Hickson, R., Petrillo, M. D., and Luster, D. G. 2003. Advances in molecular-based diagnostics in meeting crop biosecurity and phytosanitary issues. Annu. Rev. Phytopathol. 41:305-324.

38. Schena, L., Hughes, K. J. D., and Cooke, D. E. L. 2006. Detection and quantification of Phytophthora ramorum, P. kernoviae, $P$. citricola and $P$. quercina in symptomatic leaves by multiplex real-time PCR. Mol. Plant Pathol. 7:365-379.

39. Schena, L., Nigro, F., Ippolito, A., and Gallitelli, D. 2004. Real-time quantitative PCR: A new technology to detect and study phytopathogenic and antagonistic fungi. Eur. J. Plant Pathol. 110:893-908.

40. Schroeder, K. L., Okubara, P. A., Tambong, J. T., Lévesque, C. A., an Paulitz, T. C. 2006. Identification and quantification of pathogenic Pythium spp. from soils in eastern Washington using real-time polymerase chain reaction. Phytopathology 96:637-647.

41. Scott, J. B., Hay, F. S., and Wilson, C. R. 2004. Phylogenetic analysis of the downy mildew pathogen of oilseed poppy in Tasmania, and its detection by PCR. Mycol. Res. 108:198-295.

42. Silvar, C., Díaz, J., and Merino, F. 2005. Real-time polymerase chain reaction quantification of Phytophthora capsici in different pepper genotypes. Phytopathology 95:1423-1429.

43. Singer, V. L., Jones, L. J., Yue, S. T., and Haugland, R. P. 1997. Characterization of Picogreen reagent and development of a fluorescence-based solution assay for double stranded DNA quantitation. Anal. Biochem. 249:228-238.

44. Taylor, C. F., Field, D., Sansone, S. A., Aerts, J., Apweiler, R., Ashburner M., et al. 2008. Promoting coherent minimum reporting guidelines for biological and biomedical investigations: The MIBBI project. Nat. Biotechnol. 26:889-896.

45. Vaerman, J. L., Sausssoy, P., and Ingargiola, I. 2004. Evaluation of real-time PCR data. J. Biol. Regul. Homeost. Agents 18:212-214.

46. Valsesia, G., Gobbin, D., Patocchi, A., Vecchione, A., Pertot, I., and Gessler, C. 2005. Development of a high-throughput method for quantification of Plasmopara viticola DNA in grapevine leaves by means of quantitative realtime polymerase chain reaction. Phytopathology 95:672-678.

47. Vandemark, G. J., and Barker, B. M. 2003. Quantifying Phytophthora medicaginis in susceptible and resistant alfalfa with a real-time fluorescent PCR assay. J. Phytopathol. 151:577-583.

48. Wang, Y., Zhang, W., Wang, Y., and Zheng, X. 2006. Rapid and sensitive detection of Phytophthora sojae in soil and infected soybeans by speciesspecific polymerase chain reaction assays. Phytopathology 96:1315-1321.

49. Wong, M. L., and Medrano, J. F. 2005. Real-time PCR for mRNA quantitation. BioTechniques 39:75-85.

50. Zimmer, R. C., McKeen, W. E., and Campbell, C. G. 1992. Location of oospores in buckwheat seed and probable roles of oospores and conidia of Peronospora ducometi in the disease cycle on buckwheat. J. Phytopathol. 135:217-223. 